\title{
Expression of interleukin-1 (IL-1) ligands system in the most common endometriosis-associated ovarian cancer subtypes
}

\author{
Mamadou Keita', Paul Bessette ${ }^{1}$, Manuella Pelmus², Youssef Ainmelk', Aziz Aris ${ }^{1,3^{*}}$
}

\begin{abstract}
Objectives: Endometrioid carcinoma of the ovary is one of the most types of epithelial ovarian cancer associated to endometrioisis. Endometrioid tumors as well as endometriotic implants are characterized by the presence of epithelial cells, stromal cells, or a combination of booth, that resemble the endometrial cells, suggesting a possible endometrial origin of these tumors. Pro-inflammatory cytokines, including interleukin-1 (IL-1) have been reported to be involved in both endometriosis and ovarian carcinogenesis. The major objective of this study was to determine the level expression of IL-1 ligands system (IL-1 $\alpha, I L-1 \beta$ and IL-1RA) in the most common subtypes of ovarian cancer cells compared to endometrial cells.
\end{abstract}

Methods: We used primary endometrial cells, endometrial cell line RL-952 and different subtypes of epithelial ovarian cancer cell lines including TOV-112D (endometrioid), TOV-21G (clear cell) and OV-90 (serous).

Immunofluorescence and real-time PCR analysis were used respectively for detecting IL-1 ligands at the levels of cell-associated protein and mRNA. Soluble IL-1 ligands were analyzed by ELISA.

Results: We demonstrated that IL-1 ligands were expressed by all endometriosis-associated ovarian cancer subtypes and endometrial cells. In contrast to other cancer ovarian cells, endometrioid cells exhibit a specific decrease of cell-associated IL-1RA expression and its soluble secretion.

Conclusion: Endometrioid ovarian cancer exhibits an alteration in the expression of IL-1RA, a key protector against tumorogenic effects of IL-1. This alteration evokes the same alteration observed in endometriotic cells in previous studies. This suggests a possible link between the endometrium, the tissue ectopic endometriosis and endometrioid ovarian cancer.

\section{Background}

Ovarian cancer, the leading cause of death from gynecological malignancy, is the seventh most common malignancy in women worldwide. In more than two thirds of the cases are diagnosed at advanced stages [1]. Ovarian cancer has been reported in patients with pre-existing endometriosis, known as endometriosis-associated ovarian cancer (EAOC) [2,3]. It has been reported an increased risk of ovarian cancer in women with endometriosis [2,3]. Endometriosis is a common benign disease defined by the presence of endometrial glands and stroma in ectopic locations, mainly ovary and

\footnotetext{
*Correspondence: Aziz.Aris@USherbrooke.ca

'Department of Obstetrics and Gynecology, Sherbrooke University Hospital
} Centre, 3001, 12e Avenue Nord, Sherbrooke, Quebec J1H 5N4, Canada peritoneum. Ovarian endometrioid cells resemble to endometrial cells, mimicking the structure of endometrium, is one of the most frequent histological subtypes of EAOC $[2,3]$.

The menstrual phase of the endometrium and ovary includes inflammation as a physiologic component [4-9]. Thus IL-1, a major pro-inflammatory cytokine, is physiologically involved in the process of ovulation [10-14] and implantation [15,16]; and pathologically in epithelial ovarian carcinoma [17-21], endometrial tumors [9,22] and endometriosis [23]. Several experimental data support a crucial role of IL-1 as an autocrine and paracrine stimulus in murine and human carcinogenesis [24,25]. IL-1 potentates invasiveness and metastasis of malignant cells, by inducing adhesion molecule expression on tumor as well as on the endothelial cells [24-27]. 
Moreover, IL-1 increases the growth of ovarian carcinoma cells [28] and its proliferation [29].

IL-1 ligands system includes IL-1 alpha (IL-1 $\alpha)$ and IL1 beta (IL-1 $\beta$ ) which are potent active cytokines, while IL-1 receptor antagonist (IL-1 RA) acts as an inhibitor cytokine. It may exert its effects in a soluble extracellular (sIL-1RA) and intracellular (icIL-1RA) forms [30,31]. IL1 RA competes with IL- $1 \alpha$ and IL-1 $\beta$ in binding to IL-1 receptors without inducing a cellular response [32].

Many studies have shown that the concentrations of IL-1 $\beta$ were significantly increased in peritoneal fluid [33], ectopic, and eutopic endometrial cells [34] from women with endometriosis, suggesting that IL-1 $\beta$ could induce the growth, adhesion [9], invasiveness [35], and angiogenesis [36] of endometrial fragments outside of the uterus. As a competitive antagonist for IL-1 $\beta$, IL1RA is detected in eutopic endometrium but is completely decreased in peritoneal fluid [37] or absent in ectopic endometrium [38] of patients with endometriosis. This suggests that an imbalance between the levels of IL- $1 \beta$ and its natural receptor antagonist may contribute to the unrestricted growth of ectopic endometrium. However, little is known about IL-1 ligands system expression in endometrioid ovarian cells, given the hypothesis that this tissue is of endometrial origin.

Since impairment of IL- 1 activity regulation in ectopic cells may promote a neoplastic transformation in the ovary $[9,39,40]$, we hypothesized that IL-1RA may play a role in the pathogenesis of endometriosis-associated ovarian cancer.

\section{Methods}

Cells, antibodies, and others reagents

Primary epithelial cells from the endometrium, well-differentiated endometrial carcinoma RL952 and immortalized malignant endometrioid ovarian cancer cell TOV112D (EOCC), clear cell ovarian cancer cell TOV-21G, serous ovarian cancer cell OV-90 cell lines (ATCC, Rockville, MD, USA) were used. Ovarian cancer and primary endometrial cells were cultured in medium 199 and medium 105 mixtures (Invitrogen Life Technologies Inc., New York, NY). RL-952 was maintained in Dulbecco's modified Eagle's medium F-12 (GIBCO: Invitrogen, NY, USA). These media were supplemented with $10 \%$ FBS. Hanks Balanced Salt Solution containing trypsin 0.25 mM EDTA was obtained from Sigma (St. Louis, MO, USA). The concentrations of human IL- $1 \alpha$, IL- $1 \beta$ and IL-1RA in cell culture supernatants were measured by using ELISA kit (R\&D Systems Inc., Minneapolis, MN). Monoclonal mouse anti-human IL-1 $\alpha$ and IL-1RA and antibody Alexa Fluor 594-labelled goat anti-mouse were respectively purchased from R\&D Systems Inc. (Minneapolis, MN, USA) and Molecular Probes (Invitrogen, Carlsbad, CA, USA). 4, 6-diaminido-2-phenyl-indole
(DAPI) was obtained from Sigma Aldrich (St Louis, MO, USA). Reverse Transcriptase Supercript II and SYBR Green Master Mix were purchased respectively from Invitrogen (Carlsbad, CA, USA) and Applied Biosystems (Foster City, CA, USA).

\section{Tissue dissociation and epithelial endometrial cells purification}

Endometrial biopsies were obtained from 5 healthy fertile patients undergoing gynecological surgery for tubal ligation. The study was approved by the CHUS Ethics Human Research Committee on Clinical Research. All participants gave written consent. Tissues were washed in HBSS minced into small pieces and dissociated with collagenase as previously described [41]. Endometrium was finely minced and incubated in sterile Hank's balanced salt solution (HBSS) (GIBCO Invitrogen Corp., Burlington, ON, Canada) containing $20 \mathrm{mM}$ Hepes, $100 \mathrm{U} / \mathrm{ml}$ penicillin, $100 \mu \mathrm{g} / \mathrm{ml}$ streptomycin and $1 \mathrm{mg} / \mathrm{ml}$ collagenase at $37^{\circ} \mathrm{C}$ in a shaking water bath during 60 minutes. Fragments of epithelial glands from collegenase digestion were isolated by filtration through a $45-\mu \mathrm{m}$ nylon mesh.

\section{Enzyme-linked immunosorbent assay for IL-1 $\beta$ and IL-1RA proteins}

Endometrial and ovarian cancer cells were seeded at a density of $2 \times 10^{6}$ cells per $1 \mathrm{ml}$ in 12 -well plates containing medium with $10 \%$ FBS and cultured overnight. Medium was exchanged and cells were cultured for a further $48 \mathrm{hr}$. The culture supernatants were collected and microfuged at $1,500 \mathrm{rpm}$ for five min to remove particles and the supernatants frozen at $-20^{\circ} \mathrm{C}$ until use in ELISA. The concentration of IL- $1 \alpha$, IL- $1 \beta$ and IL-1RA in the supernatants per $2 \times 10^{6}$ cells was measured using an ELISA kit (R\&D Systems, Minneapolis, $\mathrm{MN}$ ) according to the manufacturer's instructions.

\section{Immunofluorescence and quantitative imaging cytometry} of IL- $1 \alpha$ and IL-1RA proteins

To evaluate intracellular, membrane-bound IL- $1 \alpha$ and intracellular IL-1RA, immunostaining was performed according to Akoum et al. [42]. Briefly, cell lines were grown on glass coverslips overnight and fixed with formaldehyde in PBS. The cells were permeabilized by treatment with $0.1 \%$ Triton X-100 (PBS/TX) in PBS for 15 $\mathrm{min}$ at room temperature and incubated with a monoclonal mouse anti-human IL-1 $\alpha$ or IL-1RA antibody in 1\% BSA/PBS for 2 hours. After washing with PBS, the cells were incubated with secondary antibody goat AntiMouse Alexa Fluor 594 for 1 hour. Nuclei were identified by 4', 6'-diamidino-2-phenylindole staining for $15 \mathrm{~min}$ at room temperature. Following mounting, cells were observed under the Leica microscope. Experiments have been done five times. Immunostained cells were scanned 
with iCys imaging cytometer (Compucyte, Cambridge, MA). Immuno-staining was detected using Argon ion $(488 \mathrm{~nm})$ excitation laser with green $(530 \mathrm{~nm} / 30 \mathrm{~nm})$ detection PMT. DNA staining was detected using violet diode $(405 \mathrm{~nm})$ excitation laser with bleu $(463 \mathrm{~nm} / 39$ $\mathrm{nm}$ ) detection PMT. Image for cellular morphology was acquired using scattering of the Argon ion laser. Scanning was performed at $0,5 \mu \mathrm{m} \times 0,25 \mu \mathrm{m}$ pixel size resolution. Cellular event selection was performed using a virtual channel obtained by adding green and blue fluorescence signals to insure detection and quantification of cytoplasmic signal. Immuno-staining intensity and cellular area were measured and used to compare IL-1 $\alpha$ and IL-1RA proteins expression between EOCC, EC and the others subtypes of ovarian cancers. An experimented scorer selected the scoring thresholds for immuno-staining intensity. All cell selections were confirmed by visualizing a gallery of at least 250 representative cells.

\section{Real time PCR analysis of IL- $1 \alpha$, IL- $1 \beta$ and IL-1RA mRNA}

IL- $1 \alpha$, IL-1 $\beta$ and IL-1RA mRNA extraction was achieved using trizol. To evaluate the level of gene expression, realtime PCR with SYBR Green dye was applied. Experiments have been done five times. The Rotor-Gene (Corbett Research, Sydney, Australia) equipment for reaction monitoring was used. $\beta$ actine gene was used as internal control. The forward sequence GAATGACgCCCTCAATCAAAGT and reverse sequence TCATCTTGGGCAGTCACATACA were used for human IL-R $\alpha$. For human IL1RA, the forward and reverse sequences were AATCCAGCAAGATGCAAGCC and ACGCCTTCGTCAGGCATATT, respectively. Forward and reverse sequences for human IL-1 $\beta$ were AAACAGATGAAGTGCTCCTTCCAGG and TGGAGAACACCACTTGTTGCTCCA respectively. For $\beta$ actine, the forward and reverse sequences were CATGTACGTTGCTATCCAGGC and CTCCTTAATGTCACGCACGAT, respectively. The PCR reaction was performed in $20 \mu$ l final volume using 36well plates. The reaction mixture contained $10 \mu$ l SyberGreenSuperMix, 100 nM of each primer (forward and reverse) and $1 \mu \mathrm{l}$ cDNA. All samples were run in duplicate. The thermal protocol was as follows: $1 \mathrm{~min} 90^{\circ} \mathrm{C}$, followed by 60 cycles $\left(20 \mathrm{~s}\right.$ at $95^{\circ} \mathrm{C}$ - denaturation, $20 \mathrm{~s}$ at $60^{\circ}$ $\mathrm{C}$ - annealing and $20 \mathrm{~s}$ at $72^{\circ} \mathrm{C}$ - elongation - when the signal was acquired). Each sample was normalized on the basis of its GAPDH content according to the formula $2^{-\left(\mathrm{OCC} \Delta \mathrm{C}_{\mathrm{T}}-\mathrm{EC} \Delta \mathrm{C}_{\mathrm{T}}\right)}, \mathrm{EC}$ representing endometrial cells; OCC, ovarian cancer cells and $\mathrm{C}_{\mathrm{T}}$ the threshold cycle.

\section{Statistical analysis}

IL- $1 \alpha$ and IL-1RA staining scores follow an ordinal scale. Data followed a parametric distribution and were shown as means $\pm \mathrm{SD}$. We used one-way analysis of variance (ANOVA) and the Bonferroni's test post hoc for multiple comparisons or the unpaired $t$-test for comparison of two groups. Statistical analyses were performed using excel and GraphPad Software, Prism 4.0 (GraphPad Software, San Diego, CA, USA). Differences were considered as statistically significant whenever a $\mathrm{P}$ value $<0.05$ occurred.

\section{Results}

Our results showed that IL- $1 \alpha$ and IL-1RA were expressed in studied cells at levels of the protein, the mRNA and the soluble for. However, IL-1 $\beta$ was not detected inside cells at level of the protein.

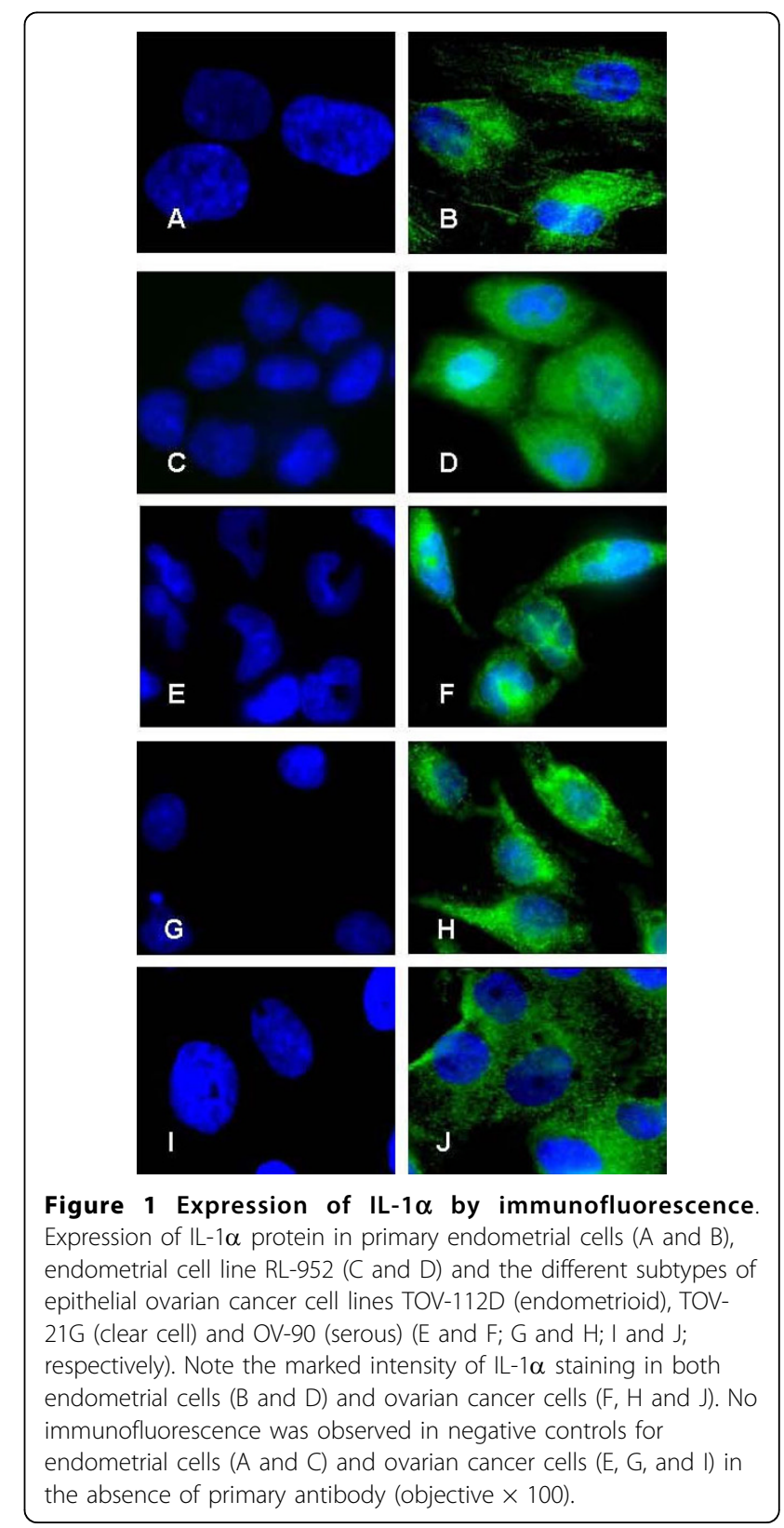




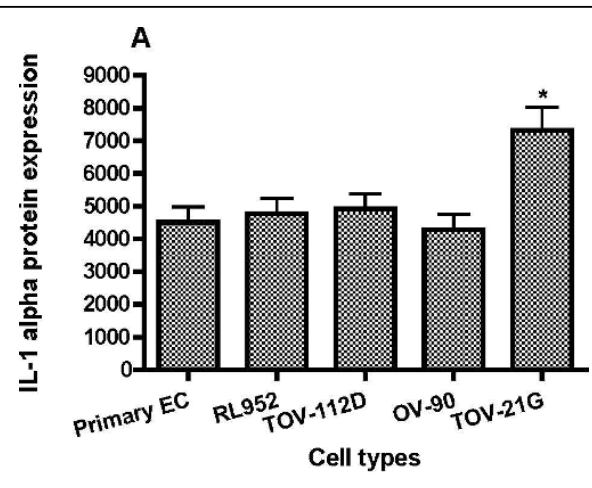

B

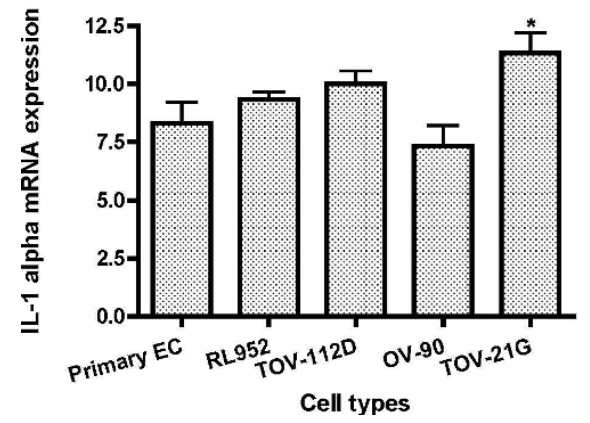

Figure 2 Graphical illustration of IL- $1 \alpha$ expression. IL-1 $\alpha$ expression scores in endometrial cells (EC) and epithelial ovarian cancer cells lines (mean \pm SD). A: IL-1 $\alpha$ was immunostained and immunofluorescence was scored using iCys imaging cytometer. B: expression of IL-1 $\alpha$ in EC and epithelial ovarian cancer cells lines was detected by real time PCR using primers specific for $\mathrm{IL}-1 \alpha$ and $\beta$-actin.

\section{Immunofluorescence analysis of cellular IL-1 $\alpha$ and IL-1RA} proteins expression

The intensity of IL-1 ligands system proteins staining was scored using quantitative imaging cytometry. Immunofluorescence analysis clearly showed that IL- $1 \alpha$ protein (Figure 1 and Figure 2A) and IL-1RA protein (Figure 3 and Figure 4A) were expressed in all types of studied cells. Whereas incubation of cells without primary antibodies (negative controls), did not result in any noticeable staining. As shown in Table 1, statistical analysis comparing endometrial cells and EAOC subtypes showed that IL-1 $\alpha$ staining was more intense in clear cell line (TOV-21G) (Figure 1 and Figure 2A; $\mathrm{P}<0.05)$, whereas IL-1RA staining was higher in serous cell line (OV-90) and very low in endometrioid ovarian cell line (TOV-112D) (Figure 3 and Figure 4A; $\mathrm{P}<0.05$ ).

\section{Analysis of IL-1 ligands gene expression by Real Time PCR}

To further analyze IL-1 $\alpha$ and IL-1RA at level of transcription, gene expression was achieved by real-time quantitative PCR kinetics using SybrGreen I chemistry.
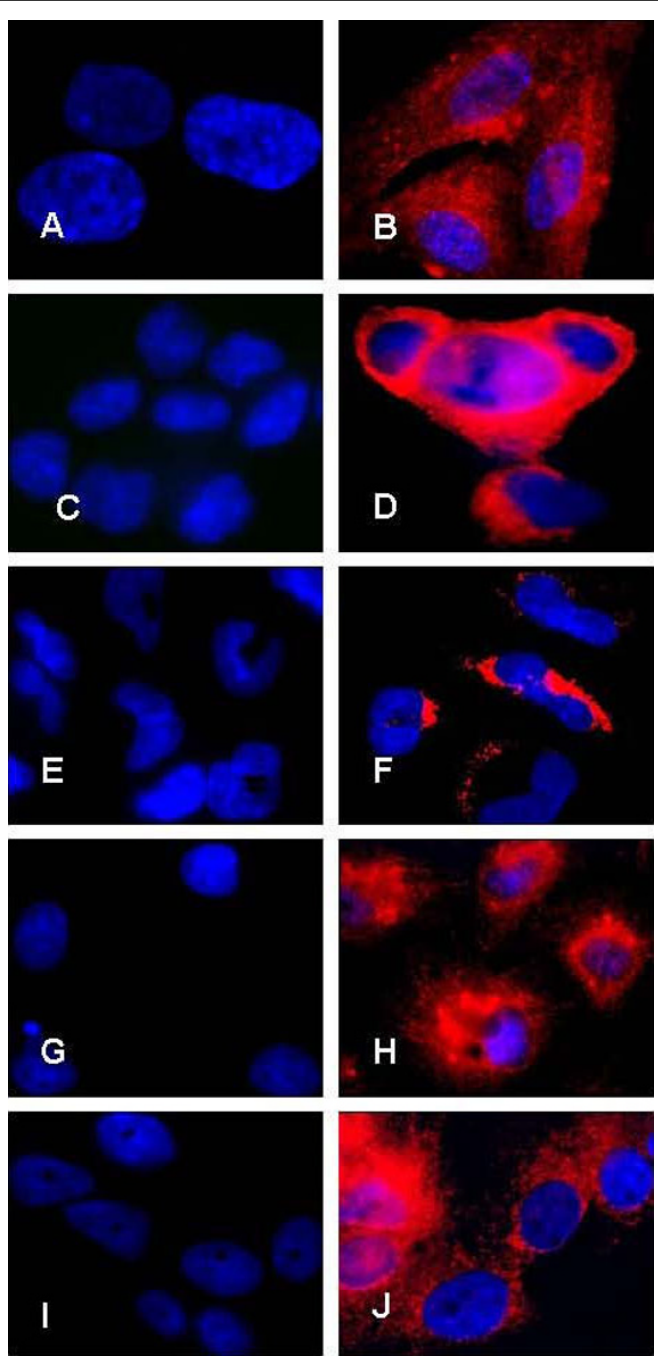

Figure 3 IL-1RA expression by immunofluorescence. Expression of IL-1RA protein in primary endometrial cells (A and B), endometrial cell line RL-952 (C and D) and the different subtypes of epithelial ovarian cancer cell lines TOV-112D (endometrioid), TOV$21 \mathrm{G}$ (clear cell) and OV-90 (serous) (E and F; G and $\mathrm{H} ; \mathrm{I}$ and J; respectively). Note the marked intensity of IL-1RA staining in both endometrial cells ( $B$ and $D$ ) and ovarian cancer cells ( $F, H$ and J). No immunofluorescence was observed in negative controls for endometrial cells ( $A$ and $C$ ) and ovarian cancer cells ( $E, G$, and $I)$ in the absence of primary antibody (objective $\times 100$ ).

The baseline adjustment method of the Rotor Gene software was used to determine the threshold cycle in each reaction. A melting curve was constructed for each primer pair to verify the presence of one gene-specific peak and the absence of primer dimmer. A representative Real-Time-PCR of IL- $1 \alpha$ and IL-1RA mRNA in EAOC subtypes compared to endometrial cell line RL-952 and primary endometrial cells are shown in Table 1. IL-1 $\alpha$ mRNA expression was higher in TOV-21G cells (Figure $2 \mathrm{~B} ; \mathrm{P}<0.05)$, whereas no statically changes of IL-1 $\alpha$ 


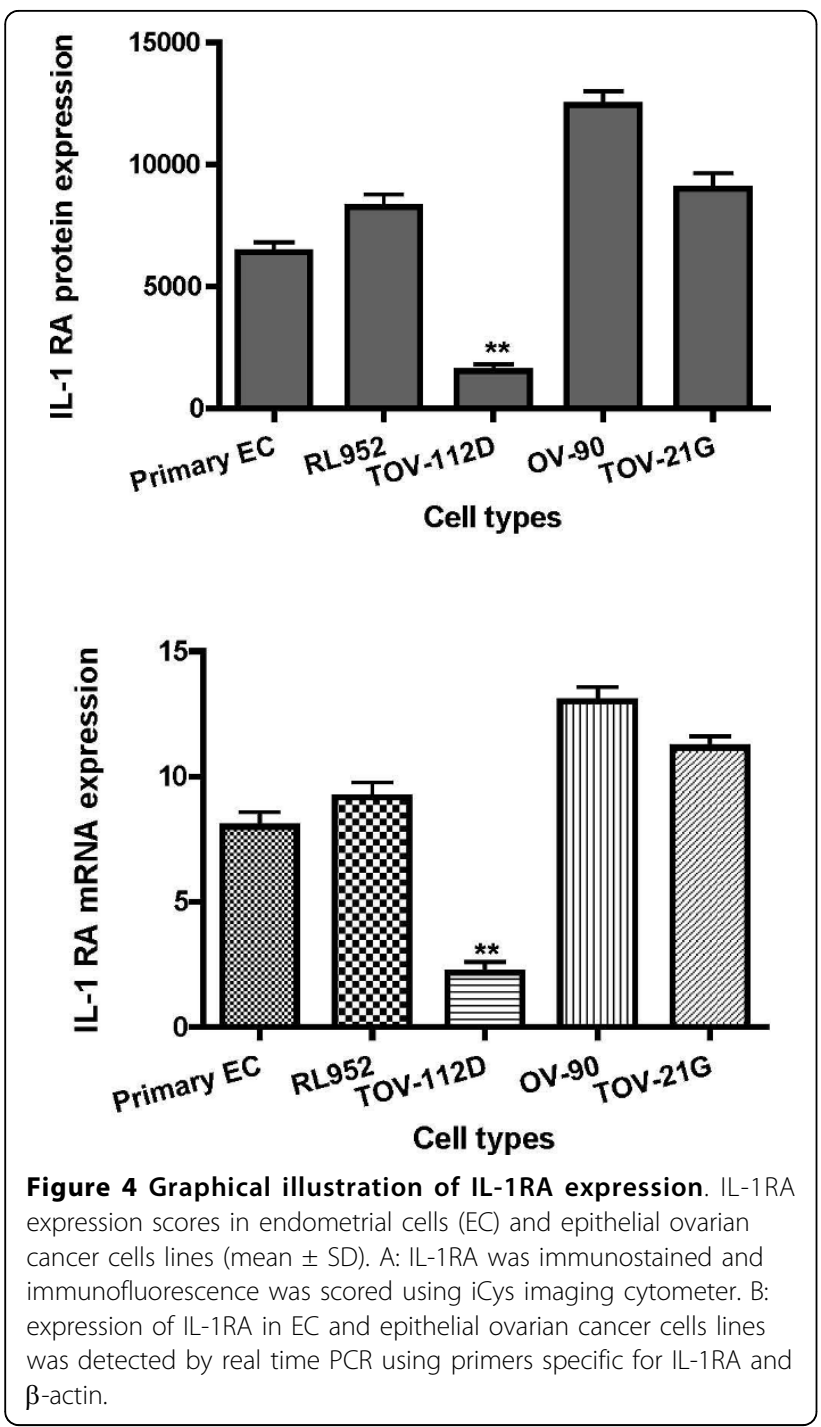

mRNA expression was observed between endometrial cells and the other epithelial ovarian cancer cell lines (Figure 2B). Analysis of mRNA levels showed a marked decrease in the expression of IL-1RA in EOCC (Figure $4 \mathrm{~B} ; \mathrm{P}<0.001)$; and an increase in the expression of IL-1 $\beta$ in TOV-112D and OV-90 cells (Table 1, Figure 5).

ELISA analysis of soluble IL-1 $\alpha$, IL-1 $\beta$ and IL-1RA

Concentrations of the cytokines released by endometrial cells and ovarian cancer cells are shown in Table 2.

The results of this study demonstrated the presence of IL- $1 \alpha$, IL-1 $\beta$ and IL-1RA in all cell lines. The levels of IL$1 \alpha$ secretion were higher in endometrial cells than ovarian cancer cells. The levels of IL- $1 \beta$ were significantly higher in the supernatant of EOCC than both of endometrial cells $(\mathrm{P}<0.05)$. The levels of IL- $1 \beta$ in the supernatant of all ovarian cancer cell lines studied were
Table 1 Comparative expression of IL-1 $\alpha$, IL-1 $\beta$ and IL-1RA in endometrial cells and epithelial ovarian cancer cell lines

\begin{tabular}{lccl}
\hline IL-1 $\alpha$ (mean \pm SD) $\mathrm{n}=5$ & Protein (intensity) & $\Delta \mathrm{Ct}: \mathrm{mRNA}$ & $2^{-\Delta \Delta \mathrm{Ct}}$ \\
\hline Primary EC (control) & $4678.6 \pm 473$ & $14.3 \pm 0.4$ & \\
RL-952 & $4948.3 \pm 167$ & $14.4 \pm 0.6$ & 1.1 \\
TOV-112D & $5217.1 \pm 391$ & $13.6 \pm 0.1$ & 1.3 \\
TOV-21G & $11320.1 \pm 391^{*}$ & $13.2 \pm 0.2$ & $1.9^{*}$ \\
OV-90 & $3897.6 \pm 590$ & $15 \pm 0.6$ & 0.8 \\
IL-1 $\beta$ (mean \pm SD) $\mathrm{n}=5$ & & & \\
\hline Primary EC (control) & & $11.4 \pm 0.6$ & \\
RL-952 & & $10.8 \pm 0.4$ & 1.3 \\
TOV-112D & & $10.0 \pm 0.3$ & $2.0^{*}$ \\
TOV-21G & & $10.7 \pm 0.3$ & 1.4 \\
OV-90 & & $9.9 \pm 0.2$ & $2.2^{*}$ \\
IL-1RA (mean \pm SD) $\mathrm{n}=5$ & & \\
\hline Primary EC (control) & $6921.1 \pm 611$ & $16.8 \pm 0.7$ & \\
RL-952 & $8391.3 \pm 241$ & $15.9 \pm 0.1$ & 1.2 \\
TOV-112D & $2101.6 \pm 352^{*}$ & $18.9 \pm 0.6$ & $0.2^{*}$ \\
TOV-21G & $8798.1 \pm 571^{*}$ & $16.1 \pm 0.4$ & 1.3 \\
OV-90 & $13251.6 \pm 495$ & $15.9 \pm 0.3$ & 1.4 \\
\hline
\end{tabular}

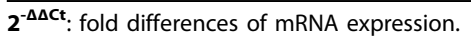

* $\mathrm{P}<0.05$, comparison to control (primary endometrial cells).

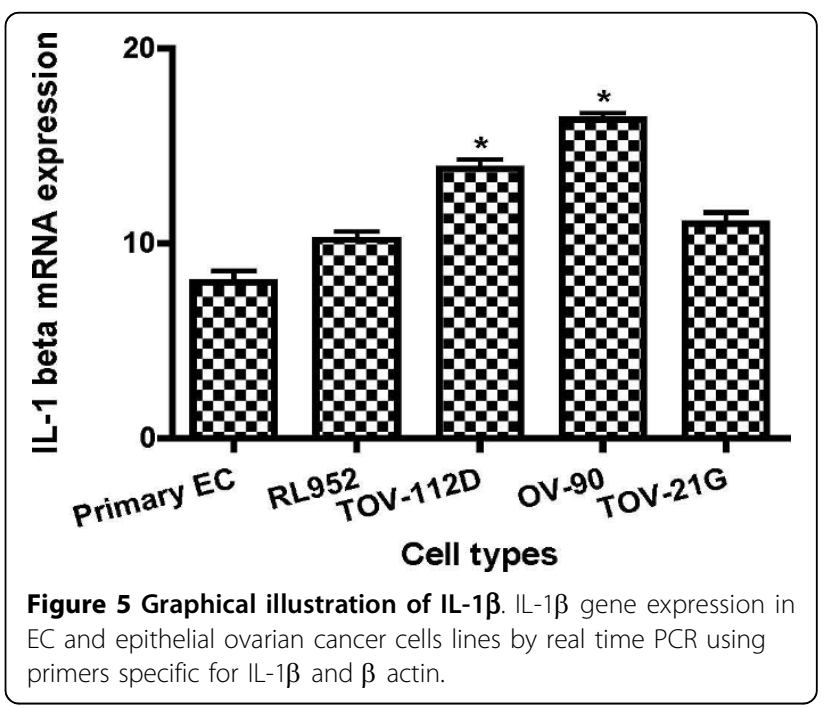

Table 2 Comparative expression of IL-1 $\beta$ and IL-1RA in endometrial cells and epithelial ovarian cancer cell lines

\begin{tabular}{lccc}
\hline Cells & IL-1 $\boldsymbol{\alpha}(\mathbf{p g} / \mathbf{m l})$ & $\mathbf{I L}-\mathbf{1} \boldsymbol{\beta}(\mathbf{p g} / \mathbf{m l})$ & IL-1 RA $(\mathbf{p g} / \mathbf{m l})$ \\
\hline $\begin{array}{l}\text { Primary EC } \\
\text { (control) }\end{array}$ & $15.50 \pm 0.4$ & $11.00 \pm 1.2$ & $154 \pm 3.9$ \\
RL-952 & $49.50 \pm 2.0$ & $13.9 \pm 0.9$ & $178 \pm 4.1$ \\
TOV-112D & $11.00 \pm 0.8$ & $22.3 \pm 2.2$ & $122 \pm 2.4$ \\
TOV-21G & $13.00 \pm 1.1$ & $21.6 \pm 1.5$ & $154 \pm 1.1$ \\
OV-90 & $12.80 \pm 1.4$ & $28.3 \pm 2.1$ & $358 \pm 5.3$ \\
\hline
\end{tabular}


significantly higher than endometrial cells $(\mathrm{P}<0.05)$. Moreover, we found a high concentration of IL- $1 \beta$ in OV-90 cell line $(\mathrm{P}<0.01)$. The levels of IL-1RA are significantly lower in EOCC compared to both endometrial cells $(\mathrm{P}<0.05)$. However, IL-1RA concentrations were also lowers in EOCC compared to other ovarian cancer cell lines, with high expression in OV-90 cell line $(\mathrm{P}<0.01)$.

\section{Discussion}

Endometriosis is more often associated with ovarian cancer. The relationship with ovarian cancer can be understood as a local process of malignant transformation. It has been reported that IL-1, a pro-inflammatory cytokine, may induce immune response disorders, which thereby may contribute to the establishment and progression of ectopic endometrial implants $[43,44]$. Impairment of the IL-1 family cytokine network may be a cause of these immune disorders which may favor local ovarian malignant transformation in women with endometriosis.

We have measured levels of IL-1 $\alpha$, IL-1 $\beta$ and IL-1RA in endometrial and ovarian cancer cells. Our present study didn't show a significant difference expression of IL-1 $\alpha$ cell-associated expression between ovarian endometrioid cancer cells (TOV-112D) and endometrial cells with high expression in clear cell cells (TOV-21G) (Figure 2 , table 1 ). In contrast, IL- $1 \alpha$ secretion levels were higher in endometrial cells than endometrioid cells (Table 2). However IL-1 $\beta$ was more expressed in TOV$112 \mathrm{D}$ cells than endometrial cells (Figure 5, table 2). These data suggested the implication of IL-1 in physiological as well as pathological processes in endometrium [9] and ovary $[10,17,21]$.

IL-1RA which is a natural regulator of IL-1, is mainly produced by macrophages, monocytes and endometrial epithelial cells $[45,46]$. Previous studies have shown a deficiency of IL-1RA expression in the ectopic and eutopic endometrium of women with endometrioisis compared to healthy controls $[38,47]$. One of the findings of this study is the significant specific decreased levels of IL-1RA at intracellular (Figure 4; Table 1) and soluble levels (Table 2) in endometrioid ovarian cancer cell compared to endometrial and ovarian cancer cells. This is of further interest given that this subtype of ovarian cancer represents the major and the one of most commonly associated to endometriosis [2,3]. One could hypothesize that after retrograde menstruation; deficiency of IL-RA coupled to over expression of IL- $1 \beta$ in women with endometriosis may lead to increased stimulation of immune cells, endometrial and ectopically implanted endometrial cells. This event may accentuate the inflammatory reaction and contribute to endometrioid ovarian cancer development. Many authors reported that in peritoneal fluid, the levels of IL-8, an angiogenesis cytokine, and VEGF are increased, suggesting their role in the pathogenesis of the disease $[48,49]$. Furthermore, it has been shown that IL-1RA can strongly inhibit endogenous IL-8 and VEGF secretion in endometrial stromal cells $[47,50]$. Therefore, reduced IL1RA levels in ectopic endometrial cells may be insufficient to inhibit the secretion of IL-8 and VEGF. These factors may facilitate their implantation and transformation to endometrioid ovarian cancer cells. IL- $1 \beta$ is regulated by IL-1RA and activates estrogen receptors, which increase the proliferation of breast cancer cells [51]. By this way, it is intriguing to speculate that IL-1RA deficiency coupled to IL-1beta over expression may lead to estrogen receptor over expression which is one the most markers of ovarian endometrioid subtype [52].

\section{Conclusions}

Our findings showed that endometrioid ovarian cancer exhibited a decrease in the expression of IL-1RA, suggesting a possible link with the ectopic endometriotic tissue which has already been found deficient in expression of IL-1RA in previous studies.

\section{List of abbreviations}

OC: ovarian cancer; EAOC: endometriosis-associated ovarian cancer; EOCC: endometrioid ovarian cancer cell.

\section{Acknowledgements \\ This work was supported in part by Canadian Institutes of Health Research (CIHR), by Fonds de la Recherche en santé du Quebec (FRSQ), and by Fondation de l'Université de Sherbrooke.}

\section{Author details}

${ }^{1}$ Department of Obstetrics and Gynecology, Sherbrooke University Hospital Centre, 3001, 12e Avenue Nord, Sherbrooke, Quebec J1H 5N4, Canada. ${ }^{2}$ Department of Pathology, Sherbrooke University Hospital Centre, 3001, 12e Avenue Nord, Sherbrooke, Quebec J1H 5N4, Canada. ${ }^{3}$ Clinical Research Centre of Sherbrooke University Hospital Centre, 001, 12e Avenue Nord, Sherbrooke, Quebec J1H 5N4, Canada.

\section{Authors' contributions}

MK: A PhD student, he carried out the molecular studies and contributed in acquisition, analysis and interpretation of data and drafting the manuscript. PB: Professor, he was involved in design, acquisition, analysis and interpretation of data.

MP: Professor, she was involved in design, acquisition, analysis and interpretation of data.

YA: Professor, he was involved in design, acquisition, analysis and interpretation of data.

AA: Professor, responsible of the project and supervisor of the research. He was involved in all steps of the work (i.e. conception, design, analysis and interpretation of data, and drafting the manuscript).

All authors read and approved the final manuscript.

\section{Competing interests}

The authors declare that they have no competing interests. 


\section{References}

1. Agarwal R, Kaye SB: Ovarian cancer: strategies for overcoming resistance to chemotherapy. Nature reviews 2003, 3:502-516.

2. Somigliana E, Vigano P, Parazzini F, Stoppelli S, Giambattista E, Vercellini P: Association between endometriosis and cancer: a comprehensive review and a critical analysis of clinical and epidemiological evidence. Gynecologic oncology 2006, 101:331-341.

3. Modesitt SC, Tortolero-Luna G, Robinson JB, Gershenson DM, Wolf JK: Ovarian and extraovarian endometriosis-associated cancer. Obstetrics and gynecology 2002, 100:788-795.

4. Vakkila J, Lotze MT: Inflammation and necrosis promote tumour growth. Nat Rev Immunol 2004, 4:641-648.

5. Pollard JW: Tumour-educated macrophages promote tumour progression and metastasis. Nat Rev Cancer 2004, 4:71-78.

6. Balkwill F, Charles KA, Mantovani A: Smoldering and polarized inflammation in the initiation and promotion of malignant disease. Cancer cell 2005, 7:211-217.

7. Apte RN, Dotan S, Elkabets $M$, et al: The involvement of IL-1 in tumorigenesis, tumor invasiveness, metastasis and tumor-host interactions. Cancer metastasis reviews 2006, 25:387-408.

8. Coussens LM, Werb Z: Inflammation and cancer. Nature 2002, 420:860-867.

9. Kharfi A, Akoum A: Correlation between decreased type-II interleukin-1 receptor and increased monocyte chemotactic protein-1 expression in the endometrium of women with endometriosis. Am J Reprod Immunol 2001, 45:193-199.

10. Townson $\mathrm{DH}$, Pate $\mathrm{J}$ : Regulation of prostaglandin synthesis by interleukin-1 beta in cultured bovine luteal cells. Biology of reproduction 1994, 51:480-485.

11. Hurwitz A, Finci-Yeheskel Z, Dushnik M, et al: Cytokine-mediated regulation of rat ovarian function: interleukin-1 inhibits plasminogen activator activity through the induction of plasminogen activator inhibitor-1 (PAI-1). Molecular and cellular endocrinology 1994, 101:307-314.

12. Kokia E, Hurwitz A, Ben-Shlomo I, Adashi EY, Yanagishita M: Receptormediated stimulatory effect of IL-1 beta on hyaluronic acid and proteoglycan biosynthesis by cultured rat ovarian cells: role for heterologous cell-cell interactions. Endocrinology 1993, 133:2391-2394.

13. Ben-Shlomo I, Adashi EY, Payne DW: The morphogenic/cytotoxic and prostaglandin-stimulating activities of interleukin-1 beta in the rat ovary are nitric oxide independent. The Journal of clinical investigation 1994, 94:1463-1469.

14. Gerard N, Caillaud M, Martoriati A, Goudet G, Lalmanach AC: The interleukin-1 system and female reproduction. The Journal of endocrinology 2004, 180:203-212.

15. Simon C, Moreno C, Remohi J, Pellicer A: Cytokines and embryo implantation. J Reprod Immunol 1998, 39:117-131.

16. Sheth KV, Roca GL, al-Sedairy ST, Parhar RS, Hamilton CJ, al-Abdul Jabbar F: Prediction of successful embryo implantation by measuring interleukin1-alpha and immunosuppressive factor(s) in preimplantation embryo culture fluid. Fertility and sterility 1991, 55:952-957.

17. Burke F, Relf M, Negus R, Balkwill F: A cytokine profile of normal and malignant ovary. Cytokine 1996, 8:578-585.

18. Punnonen R, Teisala K, Kuoppala T, Bennett B, Punnonen J: Cytokine production profiles in the peritoneal fluids of patients with malignant or benign gynecologic tumors. Cancer 1998, 83:788-796.

19. Toutirais $O$, Chartier $P$, Dubois $D$, et al: Constitutive expression of TGFbeta1, interleukin- 6 and interleukin- 8 by tumor cells as a major component of immune escape in human ovarian carcinoma. European cytokine network 2003, 14:246-255.

20. Naylor MS, Stamp GW, Foulkes WD, Eccles D, Balkwill FR: Tumor necrosis factor and its receptors in human ovarian cancer. Potential role in disease progression. The Journal of clinical investigation 1993, 91:2194-2206.

21. Li BY, Mohanraj D, Olson MC, et al: Human ovarian epithelial cancer cells cultures in vitro express both interleukin 1 alpha and beta genes. Cancer research 1992, 52:2248-2252.

22. Nishida M, Nasu K, Fukuda J, Kawano Y, Narahara H, Miyakawa I: Downregulation of interleukin-1 receptor type 1 expression causes the dysregulated expression of CXC chemokines in endometriotic stromal cells: a possible mechanism for the altered immunological functions in endometriosis. The Journal of clinical endocrinology and metabolism 2004, 89:5094-5100.
23. Kharfi A, Boucher A, Akoum A: Abnormal interleukin-1 receptor type II gene expression in the endometrium of women with endometriosis. Biology of reproduction 2002, 66:401-406.

24. lizuka N, Hazama S, Hirose K, et al: Interleukin-1 receptor antagonist mRNA expression and the progression of gastric carcinoma. Cancer letters 1999, 142:179-184.

25. Apte RN, Douvdevani A, Zoller M, et al: Cytokine-induced tumor immunogenicity: endogenous interleukin-1 alpha expressed by fibrosarcoma cells confers reduced tumorigenicity. Immunology letters 1993, 39:45-52.

26. Apte RN, Dvorkin T, Song X, et al: Opposing effects of IL-1 alpha and IL-1 beta on malignancy patterns. Tumor cell-associated IL-1 alpha potentiates anti-tumor immune responses and tumor regression, whereas IL-1 beta potentiates invasiveness. Advances in experimental medicine and biology 2000, 479:277-288.

27. Castrilli G, Tatone D, Diodoro MG, Rosini S, Piantelli M, Musiani P. Interleukin 1alpha and interleukin 6 promote the in vitro growth of both normal and neoplastic human cervical epithelial cells. British journal of cancer 1997, 75:855-859.

28. Marth C, Zeimet AG, Herold $M$, et al: Different effects of interferons, interleukin-1beta and tumor necrosis factor-alpha in normal (OSE) and malignant human ovarian epithelial cells. International journal of cancer 1996, 67:826-830.

29. Chen Z, Fadiel A, Feng Y, Ohtani K, Rutherford T, Naftolin F: Ovarian epithelial carcinoma tyrosine phosphorylation, cell proliferation, and ezrin translocation are stimulated by interleukin 1alpha and epidermal growth factor. Cancer 2001, 92:3068-3075

30. Arend WP, Malyak M, Guthridge CJ, Gabay C: Interleukin-1 receptor antagonist: role in biology. Annual review of immunology 1998, 16:27-55.

31. Arend WP: Interleukin-1 receptor antagonist: discovery, structure and properties. Progress in growth factor research 1990, 2:193-205.

32. Dripps DJ, Brandhuber BJ, Thompson RC, Eisenberg SP: Interleukin-1 (IL-1) receptor antagonist binds to the $80-\mathrm{kDa}$ IL-1 receptor but does not initiate IL-1 signal transduction. The Journal of biological chemistry 1991, 266:10331-10336.

33. Mori $H$, Sawairi $M$, Nakagawa $M$, Itoh $N$, Wada $K$, Tamaya T: Expression of interleukin-1 (IL-1) beta messenger ribonucleic acid (mRNA) and IL-1 receptor antagonist mRNA in peritoneal macrophages from patients with endometriosis. Fertility and sterility 1992, 57:535-542.

34. Bergqvist A, Bruse C, Carlberg M, Carlstrom K: Interleukin 1beta, interleukin-6, and tumor necrosis factor-alpha in endometriotic tissue and in endometrium. Fertility and sterility 2001, 75:489-495.

35. Guay S, Akoum A: Stable inhibition of interleukin 1 receptor type II in Ishikawa cells augments secretion of matrix metalloproteinases: possible role in endometriosis pathophysiology. Reproduction (Cambridge, England) 2007, 134:525-534

36. Lebovic DI, Bentzien F, Chao VA, Garrett EN, Meng YG, Taylor RN: Induction of an angiogenic phenotype in endometriotic stromal cell cultures by interleukin-1beta. Molecular human reproduction 2000, 6:269-275.

37. Zhang $X$, Wen J, Deng L, Lin J: Decreased levels of peritoneal interleukin1 receptor antagonist in patients with endometriosis and disease-related dysmenorrhea. Fertility and sterility 2007, 88:594-599.

38. Sahakian V, Anners J, Haskill S, Halme J: Selective localization of interleukin-1 receptor antagonist in eutopic endometrium and endometriotic implants. Fertility and sterility 1993, 60:276-279.

39. Lawson C, Al-Akoum M, Maheux R, Akoum A: Increased expression of interleukin-1 receptor type 1 in active endometriotic lesions. Reproduction (Cambridge, England) 2007, 133:265-274.

40. Lawson C, Bourcier N, Al-Akoum M, Maheux R, Naud F, Akoum A: Abnormal interleukin 1 receptor types I and II gene expression in eutopic and ectopic endometrial tissues of women with endometriosis. $J$ Reprod Immunol 2007, 77:75-84

41. Matthews CJ, Redfern CP, Hirst BH, Thomas EJ: Characterization of human purified epithelial and stromal cells from endometrium and endometriosis in tissue culture. Fertility and sterility 1992, 57:990-997.

42. Akoum A, Lawson C, Herrmann-Lavoie C, Maheux R: Imbalance in the expression of the activating type I and the inhibitory type II interleukin 1 receptors in endometriosis. Human reproduction (Oxford, England) 2007, 22:1464-1473. 
43. Osteen KG, Igarashi TM, Yeaman GR, Bruner-Tran KL: Steroid and cytokine regulation of matrix metalloproteinases and the pathophysiology of endometriosis. Gynecologic and obstetric investigation 2004, 57:53-54.

44. Taylor RN, Lebovic DI, Mueller MD: Angiogenic factors in endometriosis. Annals of the New York Academy of Sciences 2002, 955:89-100, discussion 118, 396-406.

45. Simon C, Frances A, Lee BY, et al: Immunohistochemical localization, identification and regulation of the interleukin-1 receptor antagonist in the human endometrium. Human reproduction (Oxford, England) 1995, 10:2472-2477.

46. Dinarello CA: Interleukin-1. Cytokine \& growth factor reviews 1997, 8:253-265.

47. Tanaka T, Sakamoto T, Mizuno K, Umesaki N, Ogita S: Human endometrial stromal interleukin-1 beta: autocrine secretion and inhibition by interleukin-1 receptor antagonist. Hormone research 2000, 53:300-304.

48. Calhaz-Jorge C, Costa AP, Santos MC, Palma-Carlos ML: Peritoneal fluid concentrations of interleukin-8 in patients with endometriosis depend on the severity of the disorder and are higher in the luteal phase. Human reproduction (Oxford, England) 2003, 18:593-597.

49. Mahnke JL, Dawood MY, Huang JC: Vascular endothelial growth factor and interleukin- 6 in peritoneal fluid of women with endometriosis. Fertility and sterility 2000, 73:166-170.

50. Elaraj DM, Weinreich DM, Varghese $S$, et al: The role of interleukin 1 in growth and metastasis of human cancer xenografts. Clin Cancer Res 2006, 12:1088-1096.

51. Speirs V, Kerin MJ, Newton CJ, et al: Evidence for transcriptional activation of ERalpha by IL-1beta in breast cancer cells. International journal of oncology 1999, 15:1251-1254.

52. Kobel M, Kalloger SE, Boyd N, et al: Ovarian carcinoma subtypes are different diseases: implications for biomarker studies. PLOS medicine 2008, 5:e232.

doi:10.1186/1757-2215-3-3

Cite this article as: Keita et al:: Expression of interleukin-1 (IL-1) ligands system in the most common endometriosis-associated ovarian cancer subtypes. Journal of Ovarian Research 2010 3:3.

\section{Submit your next manuscript to BioMed Central and take full advantage of:}

- Convenient online submission

- Thorough peer review

- No space constraints or color figure charges

- Immediate publication on acceptance

- Inclusion in PubMed, CAS, Scopus and Google Scholar

- Research which is freely available for redistribution

Submit your manuscript at www biomedcentral.com/submit 